4. RatanawaleeWimolmas.A Survey Study of Motivation in English Language Learning of First Year Undergraduate Students at

Sirindhorn International Institute of Technology (SIIT).Thailand: Thammasat University, 2013 - P.4-7.

\title{
NEW TECHNOLOGIES IN LANGUAGE LEARNING
}

\author{
Yuliya Z. Vassilyeva \\ National Research Tomsk Polytechnic University
}

The paper describes the ways of using m-learning technologies in the educational process. New technologies have become very important in our life, providing a lot of opportunities for language learning.

The aim of the article is to show how it is possible to use m-learning technologies for language learning. The main findings of this research proved that using special apps greatly contributes to the process of learning a foreign language. Finally, advantages and drawbacks of using some applications have been observed.

One of the most interesting and widely-used device, used by people is a mobile phone. The mobile phone makes phone calls, send messages, listen to music, play games, take pictures and check an e-mail.

M-learning or mobile learning is defined as "learning across multiple contexts, through social and content interactions, using personal electronic devices" [1].

Mobile learning implies the use of mobile technology, either alone or in combination with other kinds of ICT, enables learning anytime and anywhere. Learning can unfold in a variety of ways: people can use mobile devices to access educational resources, connect with others, or create content, both inside and outside classrooms. Mobile learning also provides supporting broad educational goals such as the effective administration of school systems.

There are many applications for learning English today. For example, Lingualeo, Duolingo, Words, Easy Ten, Memrise. We observe one of the most popular application - Lingualeo.

Lingualeo is a free online platform which offers a service for learning the English language. Lingualeo is available on the web, Android, iOS, Windows Phone.

Lingual personalizes each user's learning program to make learning English more effectively. First, Lingualeo offers users a placement test to determine their language skill level. The service then develops a personal training program that takes the user's skills, goals, and preferences into account. 
Lingualeo provides special learning materials in the learning process. Students can learn grammar, while completing the exercises, also improve their vocabulary, as well as reading and listening skills. They can track check their progress using special monitoring tools [2].

The most important feature is the service that allows everyone to choose real-life content the learner likes. Lingualeo account provides learners with access to most of the service's content and tools. The collection includes more than 200,000 individual learning materials, including news, entertainment and business articles, TED Talks, [10] popular songs, movie clips, stories, and jokes [3].

This app helps to solve the main problem in language learning - lack of motivation. The service uses the principle of playing games to gain the interest of learners, maximize enjoyment and pleasure, and inspire them to continue learning.

We've analyzed the advantages and disadvantages of m-learning. The advantages are the following:

1. It's convenient and flexible, allowing immediate access to the needed information, with the help of mobile devices can improve human performance.

2. Mobile phones are rather compact, handy and easy to carry around.

3. It empowers learning any time, any place, including at home, on the train, in hotels, on the way to a meeting, university.

4. It makes learning really individual through a mobile device. Students have the choice of learning content tailored to their interests, resulting in $\mathrm{m}$ learning is focused on the student.

5. The possibility of sharing tasks and working together; students and teachers can send the text by email, cut, copy and paste, transfer devices within a group, work with each other.

6. It can be combined with other types of learning, providing an interactive learning environment for students.

7. It enhances learner engagement and interaction

8. New technical devices, such as mobile phones, gadgets, gaming devices, etc. attract students who may have lost interest in education.

However, we also should consider the following possible disadvantages [4]:

1. Small screens of mobile phone limits the amount and type of the given information.

2. There is limited storage capacity for mobile phones.

3. Batteries should work regularly, and data may be lost if it is not done correctly.

4. It can be much less reliable than desktops. 
In this regard, the future of mobile learning sphere requires a joint effort of mobile manufacturers, mobile service providers, as well as an expert of learning industry.

\section{References:}

1. Настя Радужная: «Рабочие места: Айнур Абдулнасыров, основатель LinguaLeo». - Режим доступа: http://www.Lifehacker.ru /journal/2010/0319-8.htm (дата обращения 11.09.16)

2. Crompton, H. A historical overview of mobile learning: Toward learner-centered education. In Z. L. Berge \& L. Y. Muilenburg (Eds.), Handbook of mobile learning (pp. 3-14). Florence, KY: Routledge, 2013

3. Kumari Madhuri, Vikram Singh, Mobile Learning: An Emerging Learning Trend -HiTech Whitepaper, 2009.

4. «LinguaLeo - электронный ключ к взаимопониманию». - Режим доступа: http://www.BFM.ru (дата обращения 11.09.16). 